\title{
Oliceridine - a unique drug among opioid analgesics
}

\section{Ewa Gibuła-Tarłowska}

Department of Pharmacology and Pharmacodynamics, Medical University of Lublin, Poland

(iD) https://orcid.org/0000-0001-7791-0633

Corresponding author: ewa.gibula@umlub.pl

\section{Magdalena Burat}

Department of Pharmacology and Pharmacodynamics, Medical University of Lublin, Poland

(D) https://orcid.org/0000-0002-5114-2848

\section{Ewa Kędzierska}

Department of Pharmacology and Pharmacodynamics, Medical University of Lublin, Poland

(iD) https://orcid.org/0000-0002-2648-6075

\author{
DOI: https://doi.org/10.20883/medical.e464
}

Keywords: oliceridine, opioids, pain, tolerance

Published: 2020-09-29

How to cite: Gibuła-Tarłowska E, Burat M, Kedzierska E. Oliceridine - a unique drug among opioid analgesics. JMS [Internet]. 2020 Sep 29;89(3):e464. doi:10.20883/medical. e464

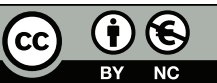

(C) 2020 by the author(s). This is an open access article distributed under the terms and conditions of the Creative Commons Attribution (CC BY-NC) licencse. Published by Poznan University of Medical Sciences

\begin{abstract}
Oliceridine is an opioid with a different mechanism of action compared to classical opioid agonists, e.g. morphine, as it does not act through active metabolites and activates the $\beta$-arrestin pathway to a small extent, thereby reducing dangerous side effects and broadening the therapeutic window. This is particularly important as, despite the wide availability of drugs from various therapeutic groups, the effectiveness of analgesics in many patients remains low. Oliceridine is a novel and effective analgesic providing rapid analgesia, with a favourable safety and tolerability profile concerning respiratory and gastrointestinal adverse effects compared to morphine, and may provide a new treatment option for patients with moderate to severe postoperative pain where an intravenous opioid is required.
\end{abstract}

\section{Introduction}

The treatment of pain is a significant challenge in modern medicine, particularly as sustained pain diminishes patients' quality of life. In addition, the lack of effective pain treatment may cause accompanying symptoms, such as anxiety, depression, reduced physical/mental performance, and limited social relationships. Therefore, there is a need to identify new analgesic substances with fewer side effects [1].

It is well known that conventional opioids have a narrow therapeutic window, with similar doses exerting the desired therapeutic effects as well as causing adverse effects [2], which is mainly related to their mechanism of action. At the cellular level, they bind to $\mu$-opioid receptors (MOR) belonging to G-protein coupled receptors (GPCRs) and non-selectively activate two crucial intracellular signalling pathways: the G-protein pathway, associated with analgesia, and the $\beta$-arrestin pathway, associated with opioid-related adverse effects and feedback inhibition of G-protein-mediated analgesia observed as receptor desensitisation. Therefore, the analgesic effect is proportionally combined with adverse effects [3], hence, there is a significant unmet need for a predictable and powerful analgesic with improved safety and tolerability compared with currently available therapies. 
Aim

This manuscript provides an overview of the information regarding oliceridine, a new selective opioid drug. The work was based on a review of international literature contained in PubMed, Google Scholar, Scopus and Web of Science literature databases and limited to the English or Polish language.

\section{Mechanism of action of olic- eridine versus opioids}

When classical opioids bind to MOR, the conformation changes detach the $\mathrm{Ga}$ and $\mathrm{G} \beta$ subunits of the heterodimeric G-protein. The $\mathrm{Ga}$ subunit inhibits the activity of adenylate cyclase, reduces the production of cyclic AMP (cAMP) and activates downstream signalling pathways, while the $\mathrm{G} \beta$ subunit inhibits voltage-gated calcium channels. Modulation of pre- and postsynaptic calcium channels causes a reduced influx of $\mathrm{Ca}^{2+}$ ions into the cell while reducing neuronal excitability, which is exacerbated by the blockage of sodium channels and TRPV1 (transient receptor potential vanilloid 1) channels [1,4]. When stimulated by an agonist, GPCR can activate many $\mathrm{G}$-protein molecules, and if unchecked, leads to the uncontrolled stimulation of cell signalling pathways. The processes that follow activation of the PCRR leading to the inhibition of its catalytic activity (called desensitisation) are regulated by the so-called $\beta$-arrestins. They belong to the group of cytosolic proteins that "arrest" the residues involved in G-protein binding, prevent the attachment of subsequent G-protein subunits to the receptor and their activation [5]. In this way, they prevent excessive activation of the receptor, leading to the suppression of the transmitted signal, but are also responsible for the occurrence of side effects, as evidenced in $\beta$-arrestin 2 knockout mice which exhibited enhanced analgesia while significantly reducing levels of respiratory depression and constipation following morphine administration [3-7]. Therefore, it is now believed that MOR ligands, which primarily activate the G-protein pathway, by showing limited $\beta$-arrestin2 recruitment may be more effective therapeutic agents with preserved analgesia and reduced side effects $[8,9]$. It should be also emphasised that the weaker receptor desensitisation due to its decreased level of $\beta$-arrestin2mediated internalisation reduces the adverse effects of GPCR agonists, slows down the development of tolerance to analgesic effects and improves the patient's quality of life [8]. The ability of these ligands to activate one selected signalling pathway has been defined as "functional selectivity", "collateral efficacy", or "biased agonism" [10-14]. A new drug belonging to this group with an atypical chemical scaffold is TRV-130 (also known as oliceridine) that acts as a full agonist for $\mathrm{G}$-protein activation but exhibits markedly reduced $\beta$-arrestin recruitment than conventional opioids [15-18].

\section{Unique pharmacological effects}

Oliceridine is characterised by rapid brain penetration which is consistent with the lipophilicity of the drug, achieving the peak analgesic effect at 5 minutes after administration compared with 30 minutes for morphine, but the duration of action for both drugs is similar, that is, approximately 90 minutes. Behavioural experiments in rodents also revealed that oliceridine has 3-10 times greater analgesic activity [15]. In a tail-flick assay, it was a 4-fold more potent analgesic than morphine, with less tolerance and opioid-induced hyperalgesia after 4 days of administration of increasing doses [19] or 3-day repeated administration, indicating a lack of tolerance development to the analgesic effect [20], whereas in the hot plate test, oliceridine was 10 -fold more potent than morphine [21]. Moreover, experiments in mice models indicated that oliceridine did not worsen allodynia or gait disturbances after trial fractures in contrast to morphine $[19,22]$.

Initially, the analgesic properties of oliceridine in rodents were considered similar to those of morphine. However, this compound induced fewer side effects, especially on the respiratory and gastrointestinal tract without the development of tolerance to its analgesic effect $[23,24]$. The lack of tolerance for analgesic effects of oliceridine is of therapeutic importance because even long-term use does not require an increasing dose to achieve the desired therapeutic effect, which also significantly reduces the potential side effects [19]. 


\section{Therapeutic application}

The promising results from behavioural studies led to controlled open-label trials, which demonstrated the efficacy and safety of oliceridine for the management of moderate to severe pain following bunionectomy (APOLLO-1) [23] or abdominoplasty (APOLLO-2) [25].

In the APOLLO-1 study, effective analgesia was observed for oliceridine at a dose of $0.1,0.35$ and $0.5 \mathrm{mg}$, however, the analgesic effect comparable to morphine was observed after treatment by two higher doses. In this trial, the respiratory safety burden showed a dose-dependent increase across oliceridine regimens (mean hours: $0.1 \mathrm{mg}$ : 0.04; $0.35 \mathrm{mg}: 0.28 ; 0.5 \mathrm{mg}: 0.8$ ) but none were statistically different from morphine (1.1). Likewise, adverse effects observed as gastrointestinal adverse reactions were also induced by oliceridine in a dose-dependent manner [23].

In the APOLLO-2 study, oliceridine at the dose of 0.35 and $0.5 \mathrm{mg}$ showed a favourable safety and tolerability profile regarding respiratory and gastrointestinal adverse effects in comparison to morphine. Likewise, the respiratory safety burden showed a dose-dependent increase after oliceridine treatment (mean hours: $0.1 \mathrm{mg}$ : 0.43; $0.35 \mathrm{mg}: 1.48$; $0.5 \mathrm{mg:} 1.59$ ) in comparison to 1.72 for morphine. Gastrointestinal adverse events induced by oliceridine also increased in a dosedependent manner but the effects were lower than for morphine [25].

Moreover, in these two pivotal efficacy studies in hard- and soft-tissue surgical models, oliceridine demonstrated a rapid (2-5 minute onset of action after intravenous administration) analgesic efficacy statistically significant vs. placebo $[23,24]$. Thus, oliceridine may provide an important new treatment option for the management of moderate to severe postoperative pain. Additionally, high skin-permeation of oliceridine suggests the possibility of research in terms of its use via a transdermal patch [15].

\section{Metabolism}

Additionally, unlike classical opioids, oliceridine undergoes hepatic metabolism to the inactive metabolites TRV0109662 and M22 [26,27] via the action of cytochrome P450 isoenzymes
(CYP3A4 and CYP2D) during oxidation and finally, glucuronidation. Most metabolites are excreted in the urine, some with faeces. Meanwhile, it is well known that classical opioids act through active metabolites excreted by the kidneys, which may lead to their accumulation and damage to nephron structures. Due to the different metabolism of oliceridine, it can be safely used in patients with renal failure without dosage adjustments. However, considering the hepatic metabolism of this compound, it is necessary to reduce its dose in severe liver failure $[17,27]$.

\section{Side effects and precautions}

The first clinical trials in healthy volunteers showed less pronounced side effects compared to classical opioids, demonstrating that oliceridine was safe and well-tolerated in a medically heterogeneous patient population, including the elderly, obese, and patients with comorbid conditions such as diabetes and sleep apnoea. The most common adverse reactions were nausea, vomiting, dizziness, headache, constipation, pruritus, and hypoxia [27]. Cardiovascular side effects such as lowered blood pressure and reduced heart rate were dose-dependent [18]. It should be emphasised that the prolongation of the QT interval in the ECG recording and respiratory depression were risk factors against the approval of oliceridine [28]. Unfortunately, although oliceridine may be safer than conventional opioids, prevailing evidence suggests that it will retain opioid-like abuse-related effects particularly during repeated treatment $[250,21,29]$.

Additionally, special attention should be paid in the case of prolonged use of oliceridine during pregnancy, since it can result in neonatal opioid withdrawal syndrome [30]. Furthermore, concomitant use with benzodiazepines or other CNS depressants, including alcohol, may result in life-threatening complications such as profound sedation, respiratory depression, coma, and even death [31]. Moreover, oliceridine is contraindicated in patients with significant respiratory depression, acute or severe bronchial asth$m a$ in an unmonitored setting or the absence of resuscitative equipment, known or suspected gastrointestinal obstruction and hypersensitivity to oliceridine. 
Finally, oliceridine was approved by the U.S. Food and Drug Administration (FDA) in adults for the management of acute pain severe enough to require an intravenous opioid analgesic and for whom alternative treatments are inadequate.

\section{Summary}

Currently, opioid analgesics are of great importance in medicine and their associated side effects do not exclude them from basic pharmacotherapy of high-intensity pain. However, oliceridine is a promising new analgesic drug with unique functional selectivity ("biased" agonism) which allows the therapeutic effect to be separated from the side effects previously considered inextricably linked to the mechanism of opioid action. Therefore, it may offer new therapeutic possibilities as a more effective and safer compound, especially for patients with moderate to severe postoperative pain requiring an intravenous opioid.

\section{Acknowledgements}

\section{Conflict of interest statement}

The authors declare no conflict of interest.

\section{Funding sources}

There are no sources of funding to declare.

\section{References}

1. Stein C. Opioid Receptors. Annual Review of Medicine. 2016 Jan 14;67(1):433-451. https://doi. org/10.1146/annurev-med-062613-093100

2. Sadhasivam S, Chidambaran V. Pharmacogenomics of opioids and perioperative pain management. Pharmacogenomics. 2012 Nov;13(15):1719-1740. https://doi.org/10.2217/pgs.12.152

3. Bohn LM, Lefkowitz RJ, Gainetdinov RR, Peppel $\mathrm{K}$, Caron MG, Lin F. Enhanced Morphine Analgesia in Mice Lacking $\beta$-Arrestin 2. Science. $1999 \mathrm{Dec}$ 24;286(5449):2495-2498. https://doi.org/10.1126/ science.286.5449.2495

4. Corder G, Castro DC, Bruchas MR, Scherrer G. Endogenous and Exogenous Opioids in Pain. Annual Review of Neuroscience. 2018 Jul 8;41(1):453-473. https:// doi.org/10.1146/annurev-neuro-080317-061522

5. Szymiczek M, Kurowska E, Gorczyca W. Rola arestyn w sygnalizacji wewnatrzkomórkowej [Role of arrestins in intracellular signaling]. Postepy Hig Med Dosw. 2005 Jul 8;59:324-33. PMID 16012393

6. Maguma HT, Dewey WL, Akbarali HI. Differences in the characteristics of tolerance to $\mu$-opioid receptor agonists in the colon from wild type and $\beta$-arrestin2 knockout mice. European Journal of Pharmacology. 2012 Jun;685(1-3):133-140. https://doi.org/10.1016/j. ejphar.2012.04.001

7. Raehal KM, Walker JKL, Bohn LM. Morphine Side Effects in $\beta$-Arrestin 2 Knockout Mice. Journal of Pharmacology and Experimental Therapeutics. 2005 May 25;314(3):1195-1201. https://doi.org/10.1124/ jpet.105.087254

8. Cheng J, Cheng T, Li W, Liu G, Zhu W, Tang Y. Computational insights into the G-protein-biased activation and inactivation mechanisms of the $\mu$ opioid receptor. Acta Pharmacologica Sinica. 2017 Nov 30;39(1):154164. https://doi.org/10.1038/aps. 2017.158

9. Raehal K, Bohn L. $\beta$-arrestins: regulatory role and therapeutic potential in opioid and cannabinoid receptor-mediated analgesia. Handb Exp Pharmacol. 2014;219:427-43. https://doi.org/10.1007/978-3 -642-41199-1_22 PMID 24292843

10. Bohn L. Selectivity for $G$ protein or arrestin-mediated signaling. In: Neve K, ed. Functional Selectivity of G Protein-Coupled Receptor Ligands. Humana Press; 2009:71-85.

11. Kenakin T. New Concepts in Drug Discovery: Collateral Efficacy and Permissive Antagonism. Nature Reviews Drug Discovery. 2005 Nov;4(11):919-927. https://doi.org/10.1038/nrd1875

12. Kenakin T. Biased agonism. F1000 Biology Reports. 2009 Nov 26;1. https://doi.org/10.3410/b1-87

13. Mailman RB. GPCR functional selectivity has therapeutic impact. Trends in Pharmacological Sciences. 2007 Aug;28(8):390-396. https://doi.org/10.1016/j. tips.2007.06.002

14. Urban JD, Clarke WP, von Zastrow $M$, Nichols $D E$, Kobilka B, Weinstein H, Javitch JA, Roth BL, Christopoulos A, Sexton PM, Miller KJ, Spedding M, Mailman RB. Functional Selectivity and Classical Concepts of Quantitative Pharmacology. Journal of Pharmacology and Experimental Therapeutics. 2006 10.1124/jpet.112.2016166 27;320(1):1-13. https://doi. org/10.1124/jpet.106.104463

15. DeWire SM, Yamashita DS, Rominger DH, Liu G, Cowan CL, Graczyk TM, Chen X, Pitis PM, Gotchev D, Yuan C, Koblish M, Lark MW, Violin JD. A G Protein-Biased Ligand at the $\mu$-Opioid Receptor Is Potently Analgesic with Reduced Gastrointestinal and Respiratory Dysfunction Compared with Morphine. Journal of Pharmacology and Experimental Therapeutics. 2013 Jan 8;344(3):708717. https://doi.org/10.1124/jpet.112.201616

16. Manglik A, Lin H, Aryal DK, McCorvy JD, Dengler D, Corder G, Levit A, Kling RC, Bernat V, Hübner $H$, Huang $X$, Sassano MF, Giguère PM, Löber $S$, Da Duan, Scherrer G, Kobilka BK, Gmeiner P, Roth BL, Shoichet BK. Structure-based discovery of opioid analgesics with reduced side effects. Nature. 2016 Aug 17;537(7619):185-190. https://doi.org/10.1038/ nature19112

17. Nafziger AN, Arscott KA, Cochrane K, Skobieranda F, Burt DA, Fossler MJ. The Influence of Renal or Hepatic Impairment on the Pharmacokinetics, Safety, and Tolerability of Oliceridine. Clinical Pharmacology in Drug Development. 2019 Nov 7;9(5):639-650. https://doi.org/10.1002/cpdd.750 
18. Viscusi ER, Webster L, Kuss M, Daniels S, Bolognese JA, Zuckerman S, Soergel DG, Subach RA, Cook E, Skobieranda F. A randomized, phase 2 study investigating TRV130, a biased ligand of the $\mu$-opioid receptor, for the intravenous treatment of acute pain. PAIN. 2016 Jan;157(1):264-272. https://doi.org/10.1097/j. pain. 0000000000000363

19. Liang D, Li W, Nwaneshiudu C, Irvine K, Clark JD. Pharmacological Characters of Oliceridine, a $\mu$-Opioid Receptor G-Protein-Biased Ligand in Mice. Anesthesia \& Analgesia. 2019 Nov;129(5):1414-1421. https:// doi.org/10.1213/ane.0000000000003662

20. Altarifi AA, David B, Muchhala KH, Blough BE, Akbarali $H$, Negus SS. Effects of acute and repeated treatment with the biased mu opioid receptor agonist TRV130 (oliceridine) on measures of antinociception, gastrointestinal function, and abuse liability in rodents. Journal of Psychopharmacology. 2017 Feb;31(6):730739. https://doi.org/10.1177/0269881116689257

21. Austin Zamarripa C, Edwards SR, Qureshi HN, Yi JN, Blough BE, Freeman KB. The G-protein biased muopioid agonist, TRV130, produces reinforcing and antinociceptive effects that are comparable to oxycodone in rats. Drug and Alcohol Dependence. 2018 Nov;192:158-162. https://doi.org/10.1016/j. drugalcdep.2018.08.002

22. Gan T, Wase L. Oliceridine, a G protein-selective ligand at the mu-opioid receptor, for the management of moderate to severe acute pain. Drugs of Today. 2020;56(4):269. https://doi.org/10.1358/ dot.2020.56.4.3107707

23. Gan T, Wase L. Oliceridine, a G protein-selective ligand at the mu-opioid receptor, for the management of moderate to severe acute pain. Drugs of Today. 2020;56(4):269. https://doi.org/10.1358/ dot.2020.56.4.3107707

24. Viscusi ER, Skobieranda F, Soergel DG, Cook E, Burt DA, Singla N. $<$ p $>$ APOLLO-1: a randomized placebo and active-controlled phase III study investigating oliceridine (TRV130), a G protein-biased ligand at the \&micro;-opioid receptor, for management of mod- erate-to-severe acute pain following bunionectomy</p>. Journal of Pain Research. 2019 Mar;Volume 12:927-943. https://doi.org/10.2147/jpr.s171013

25. Pedersen MF, Wróbel TM, Märcher-Rørsted E, Pedersen DS, Møller TC, Gabriele F, Pedersen H, Matosiuk D, Foster SR, Bouvier M, Bräuner-Osborne $\mathrm{H}$. Biased agonism of clinically approved $\mu$-opioid receptor agonists and TRV130 is not controlled by binding and signaling kinetics. Neuropharmacology. 2020 Apr;166:107718. https://doi.org/10.1016/j. neuropharm.2019.107718

26. Singla N, Skobieranda F, Soergel D, Salamea M, Burt D, Demitrack M, Viscusi E. APOLLO-2: A Randomized, Placebo and Active-Controlled Phase III Study Investigating Oliceridine (TRV130), a G Protein-Biased Ligand at the $\mu$-Opioid Receptor, for Management of Moderate to Severe Acute Pain Following Abdominoplasty. Pain Pract. 2019 Sep;19(7):715-31. https://doi. org/10.1111/papr.12801 PMID 31162798

27. Fossler MJ, Sadler BM, Farrell C, Burt DA, Pitsiu M, Skobieranda F, Soergel DG. Oliceridine (TRV130), a Novel G Protein-Biased Ligand at the $\mu$-Opioid Receptor, Demonstrates a Predictable Relationship Between Plasma Concentrations and Pain Relief. I: Development of a Pharmacokinetic/Pharmacodynamic Model. The Journal of Clinical Pharmacology. 2018 Feb 7;58(6):750-761. https://doi.org/10.1002/jcph.1076

28. Soergel DG, Ann Subach R, Sadler B, Connell J, Marion AS, Cowan CL, Violin JD, Lark MW. First Clinical Experience With TRV130: Pharmacokinetics and Pharmacodynamics in Healthy Volunteers. The Journal of Clinical Pharmacology. 2014 Jan 28;54(3):351357. https://doi.org/10.1002/jcph.207

29. Negus SS, Freeman KB. Abuse Potential of Biased Mu Opioid Receptor Agonists. Trends in Pharmacological Sciences. 2018 Nov;39(11):916-919. https:// doi.org/10.1016/j.tips.2018.08.007

30. Trevena Announces FDA Approval of OLINVYK ${ }^{\mathrm{TM}}$ (Oliceridine) Injection.

31. William E, James C. Oliceridine Injection. Internal Medicine Alert. 2020 Sep;42(17). 